\title{
Seven approaches to research in socio-ecological practice \& five insights from the RWC-Schön-Stokes model
}

\author{
Wei-Ning Xiang ${ }^{1}$
}

Received: 2 January 2021 / Accepted: 19 January 2021 / Published online: 8 March 2021

(c) Springer Nature Singapore Pte Ltd. 2021

\begin{abstract}
In this review article, I examine seven commonly used approaches to research in socio-ecological practice and share insights about their defining characteristics, similarities, differences and connections. I derived these approaches and gained insights through the RWC-Schön-Stokes model, a theoretical framework for codifying, tabulating, examining and comparing multiple ways of methodical knowing in socio-ecological systems. For this reason, I begin with an introduction of the model and, in a chronological order, provide a review of its association with three intellectual ancestors: the Bush linear model (1945), the Stokes quadrant model (1997) and the Schön-Stokes model (2017).
\end{abstract}

Keywords The RWC-Schön-Stokes model · Socio-ecological practice · Socio-ecological practice research · Ecopracticology $\cdot$ Pasteur's quadrant $\cdot$ Approach to research

I dedicate this article to the inspirations of Li Bing, West Churchman, R. Buckminster Fuller, Ian McHarg, Horst Rittel, Donald Schön, Donald Stokes and Melvin Webber

\section{A model that helped answer questions and inspired new lines of inquiry}

In a 2017 article "Pasteur's quadrant: an appealing ecophronetic alternative to the prevalent Bohr's quadrant in ecosystem services research" (Xiang 2017), I propose the Schön-Stokes model of research in socio-ecological systems (the Schön-Stokes model, for short) with a dual intention: to respond to an important research question and to inspire a new line of inquiry.

Wei-Ning Xiang

wxiang@uncc.edu

1 University of North Carolina at Charlotte, Charlotte, NC, USA

\subsection{An explanation and a new line of inquiry in $\mathbf{2 0 1 7}$}

In this 2017 article, I raise the following question concerning the widely acknowledged untenable status quo the enterprise of ecosystem services research found itself in while pursuing the honorable ambition to facilitate practitioners in socioecological practice (Xiang 2017, p.2242) ${ }^{1}$ :

Why is it that a scholarly enterprise aiming to inform, influence, or even direct practitioners [sic] demonstrated so little research interest in practical implementation and made so insignificant effort to push the envelope $?^{2}$

\footnotetext{
1 "Socio-ecological practice is the human action and social process that take place in specific socio-ecological context to bring about a secure, harmonious and sustainable socio-ecological condition serving human beings' need for survival, development and flourishing. It is the most fundamental and arguably primordial social practice Homo sapiens has been involuntarily engaging in over thousands of years of co-evolution with nature." It "includes six distinct yet intertwining classes of human action and social process-planning, design, construction, restoration, conservation and management." (Xiang 2019a, p.7) A closely related concept is "socio-ecological practice research" or "ecopracticology," which is defined as "the study of socio-ecological practice" (Ibid.).

2 [1] Throughout the article, all parentheses in direct quotations are by the author of this article unless noted otherwise. [2] In-text citations in the original passage are omitted here by the author of this article.
} 
The question was intriguing and motivated me to conduct an extensive search for explanations. The search first led to the development of an overarching theoretical frameworkthe Schön-Stokes model (Xiang 2017, pp.2242-2245); it then enabled me to dig for answers through this new lens of high magnifying power. In the end of this process, I was able to bring to light a rarely explicated explanation which is arguably more plausible than those previously available. That is, ecosystem services researchers' blanket adoption and uncritical use of a pure basic research approach from Bohr's quadrant in the Schön-Stokes model (Ibid., pp.2242-2243; a detailed account of Bohr's quadrant is provided later in Sect. 2 of this article).

The Schön-Stokes model also inspired me to raise a series of questions with special reference to the practical implementation and ensuing impacts of the ecosystem services knowledge that researchers produced and reported in credible publications [For these questions, see Xiang (2017, p.2241)]. This later led to the development of a new line of inquiry - the knowledge implementation \& impact research (i.e., knowledge I\&I research)—which aims to benefit both socio-ecological practice and socio-ecological practice research [Xiang 2019a, p.10, p.12; 2019b, pp.1-2].

Since then, the model and its undergirding ideas have been gaining traction among scholars from around the world. They were used to serve essentially the same dual purpose across different areas of socio-ecological practice and research: responding to intriguing research questions and inspiring new lines of inquiry. Below are a few examples.

\subsection{Response to a question about multiple ways of methodical knowing in 2020}

In 2020, a team of scholars was commissioned by the National Academies of Sciences, Engineering and Medicine of the USA to conduct a project entitled "Advancing a systems approach to studying the earth: a strategy for the National Science Foundation" (the National Academies of Sciences, Engineering and Medicine 2020). On November 20, at "Integrating earth systems science and engineering: a virtual workshop," they asked,

"How may systems thinking approaches vary between systems thinking in engineering versus systems thinking in the natural and social sciences?"

To respond to their question, in an invited presentation at the workshop, I used an updated version of the Schön-Stokes model as a frame of reference to highlight the differences and similarities among seven ways of methodical knowing - approaches to research-in socio-ecological systems (Xiang 2020a). This 2020 version will be presented in Sect. 4 of this article and the seven approaches discussed in Sects. 5 and 6.

\subsection{Other lines of inquiry the model has inspired since 2017}

In addition, the Schön-Stokes model and its undergirding ideas have inspired many other inquiries. These include, inter alia,

1. demonstrating the differences between theories of practice and theories of science, between practitioner-theorists and academic theoreticians (Xiang 2020b, pp.122123);

2. explaining "a gulf [that] commonly divides theory and practice in scholarly literature" (Bryant \& Turner 2019, p.328);

3. substantiating a "crucial" paradigm shift "from the traditional Bohr's quadrant to Pasteur's quadrant" in ecosystem services research (Feng et al. 2019, p.111);

4. characterizing the knowledge domain of ecopracticology-the study of socio-ecological practice (Xiang 2019a, pp.8-9) and categorizing research article types for the journal Socio-Ecological Practice Research (Xiang 2019b, pp.1-2);

5. showcasing exemplary works of Scottish-American scholar-practitioner Ian McHarg (Bryan \& Turner 2019, p.328, p.335; Xiang 2019c, pp.362-363; Yang \& Li 2019, p.210);

6. advocating the key yet overdue action to "overhaul entrenched mindset and inertia" in urban forestry practice and research (Jim 2019, p.49);

7. justifying the need for knowledge brokering in the socio-ecological practice of urban green infrastructure planning and analyzing the challenges (La Rosa 2019, pp.89-90; Wang et al. 2018, p.141);

8. conceptualizing an empirical survey in urban green infrastructure research (Hagemann et al. 2020, p.286); and

9. developing a "problem-research-practice framework" for improving the practical relevance of ecosystem services mapping (Chen et al. 2019, p.2).

\subsection{Where does the model get its power from?}

The Schön-Stokes model is a retrofit of a 1997 quadrant model of research by American political scientist Donald Stokes (1927-1997) and as such inherits much of the intellectual merit and representation power from its ancestor. This intellectual root is elaborated next before a full-scale presentation and an update of the Schön-Stokes model in Sects. 3 and 4 , respectively. 


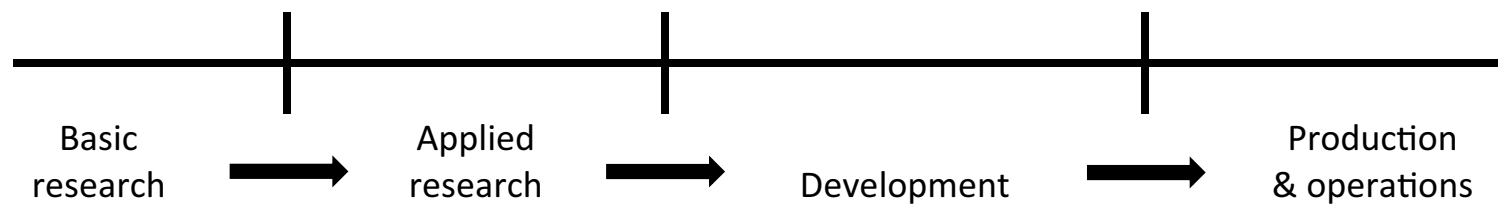

Fig. 1 The Bush linear model of research in science and technology (1945) [after Stokes' illustration of 'the endlessly popular 'linear model,' a sequence extending from basic research [via applied research] to new technology” (Stokes 1997, p.10)]

\section{The 1997 Stokes quadrant model of research in science and technology}

\subsection{A quadrant model that derives from a 1945 linear model}

In his posthumous 1997 book 'Pasteur's quadrant: basic science and technological innovation," Donald Stokes critically examined "Science: the endless frontier," an influential 1945 report by American electrical engineer Vannevar Bush (1890-1974) to the President of the USA (Bush 1945). ${ }^{3} \mathrm{He}$ expanded Bush's "endlessly popular "linear model'" of research (Stokes 1997, p.10; Fig. 1; the Bush linear model, hereafter) to a "quadrant model of scientific research" in science and technology (Ibid., p.73). For the sake of discussion in this article, I name it the Stokes quadrant model of research in science and technology (the Stokes quadrant model, for short) and illustrate in Fig. 2.

\subsection{The four quadrants}

In constructing the quadrant model, Stokes began with an analysis of the goals of understanding and use in scientific and technological research. He recast the widely accepted view of the tension between the two (Armacost 1997, p.vii) vividly via two intersecting straight-line axes, each presenting one of what he called the "dual dichotomy" of research motivations (Stokes 1997, p.72; see Fig. 2). On the "fourfold table with cells or quadrants" such derived (Ibid.), he subsequently defined the quadrants and instantiated them with conspicuous examples of distinguished researchers. Here, Donald Stokes used the term "quadrant" as a synonym for an ensemble of approaches to research. Philosophers of science would interpret "quadrant" as a synonym for paradigm of methodical knowing or research. In planning literature published in Chinese language, "quadrant" in this context is translated as 范式(paradigm) [e.g., Xiang (2020e, pp.viii-x)].

\footnotetext{
${ }^{3}$ For the historical context in which Bush developed the report and the relevance of his work to the contemporary policy debate in the USA on "the best way to organize and oversee scientific research in pursuit of innovation" (Gibson 2020, p.258), see Gibson (2020) and National Academies of Sciences, Engineering, and Medicine (2020).
}

He labeled the upper left cell in the table (Fig. 2) as Bohr's quadrant of pure basic research and noted that Niels Bohr (1885-1962), the Danish physicist and the 1922 Nobel laureate in physics for his contributions to the understanding of atomic and molecular structure and quantum theory (Aaserud 2020), "brilliantly exemplified the scholar-scientist engaged in a pure search for understanding." (Stokes 1997, p.24) "[H]owever much his ideas later remade the world," added Stokes, "clearly Niels Bohr's quest of a model atomic structure was a pure voyage of discovery." (Ibid., p.73).

He called the lower right cell Edison's quadrant of pure applied research and acknowledged that Thomas Edison (1847-1931), the self-educated American inventor and businessman who held 1,093 US patents in his name (Conot et al. 2020; US National Archives \& Records Administration 2020), "exemplified the applied investigator wholly uninterested in the deeper scientific implications of his discoveries." (Stokes 1997, p.24) The designation is appropriate, he explained, because it is reminiscent of "how strictly this brilliant inventor kept his co-workers at Menlo Park [in New Jersey], in the first industrial research laboratory in America, from pursuing the deeper scientific implications of what they were discovering in their headlong rush toward commercially profitable electric lighting." (Ibid., p.74).

Research is inspired by:

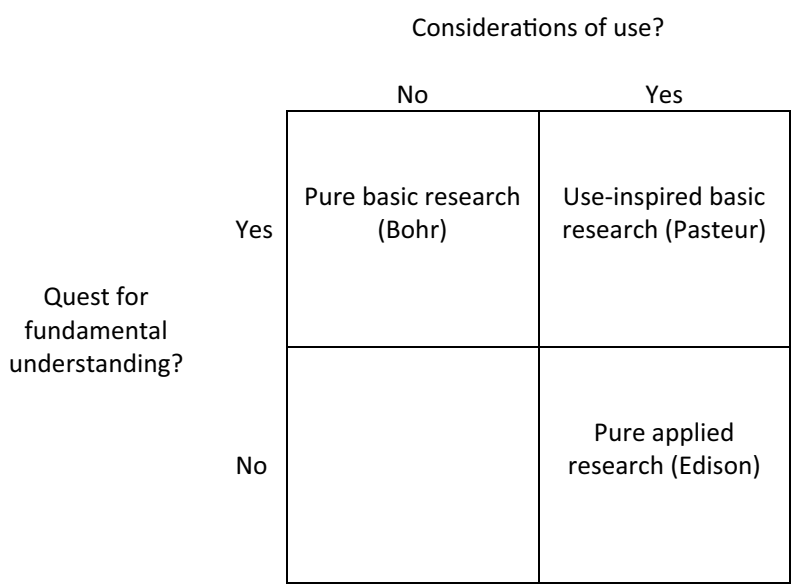

Fig. 2 The Stokes quadrant model of research in science and technology (1997) [after "Fig. 3-5. Quadrant Model of Scientific Research" (Stokes 1997, p.73)] 
In between these two, on the upper right corner is Pasteur's quadrant of use-inspired basic research, named after French chemist and microbiologist Louis Pasteur (1822-1895) who was known for his discoveries of the scientific principles of vaccination, microbial fermentation and pasteurization (Ullmann 2020). Explaining this designation, Stokes wrote, the blend of applied research with basic research was "characterized virtually the whole of Pasteur's later career. He probed ever more deeply into the processes of microbiology by accepting applied problems [i.e., realworld problems practitioners encountered] ... Many of his detailed lines of inquiry, such as the experiments by which he developed the process of the 'pasteurization' of milk or his experiments in growing attenuated bacterial strains to immunize patients from disease, are unintelligible apart from his applied goals [of solving real-world problems practitioners encountered]. The mature Pasteur never did a study that was not applied, as he laid out a whole new branch of science [of microbiology]." (Stokes 1997, p.13). ${ }^{4}$

Finally, he noted that the lower left-hand quadrant, "which includes research that is inspired neither by the goal of understanding nor by the goal of use, is not empty [sic]." (Stokes 1997, p.74) Instead, the research in this quadrant could be motivated by a range of factors, including curiosity, circumstantial needs and utilitarian considerations (Ibid., pp.74-75). Further, regardless their motivations, "studies in the fourth quadrant can be important precursors of research in Bohr's quadrant, as it was in the case of Charles Darwin's masterpiece The Origin of Species, as well as of research in Edison's quadrant." (Ibid., p.75) He nonetheless did not fill the quadrant with a description, nor did he give a name to it (Fig. 2).

\subsection{Four approaches to research}

With the fourfold table (Fig. 2), Donald Stokes in fact identified and presented four distinct approaches to research in science and technology, each exemplifying a "category" of alike approaches in a quadrant (Stokes 1997, pp.73-74). Here, an approach to research is a way of methodical knowing and acting that over the years researchers, be they

\footnotetext{
${ }^{4}$ [1] What does "The mature Pasteur" mean? Stokes explained, " $[\mathrm{t}]$ his mix of goals [of fundamental understanding and use] was not visible in the young Pasteur. The 22-year-old chemist who immersed himself in the enigma of racemic acid was engaged in a pure quest of understanding... [But] as Pasteur's scientific studies became progressively more fundamental, the problems he chose and the lines of inquiry he pursued became progressively more applied." (Stokes 1997, p.13) [2] In a 2018 article, Dutch scholar of science and innovation Robert J.W. Tijssen adds a third dimension of "[research] outputs and impacts" to the 1997 Stokes model and expands Pasteur's Quadrant to what he calls "Pasteur's Cube" (Tijssen 2018, p.1630 \& p.1632).
}

scientists or non-scientists, have developed, used and retrofit in their professional and/or academic practice and is later codified by researchers themselves or others (Xiang 2020a). These four approaches are (1) curiosity-inspired pure basic research for understanding, as exemplified by the work of Niels Bohr; (2) use-inspired basic research for understanding and use, by the work of Louis Pasteur; (3) use-inspired pure applied research for use, by the work of Thomas Edison; and (4) free roam, precursor research.

It is noteworthy that all four approaches identified, according to Stokes, are equally applicable to research in natural, physical and social sciences. For example, he noted, "this category [of use-inspired basic research for understanding and use in Pasteur's quadrant] includes the major work of John Maynard Keynes, the fundamental research of the Manhattan Project and Irving Langmuir's surface physics." (Stokes 1997, p.74) ${ }^{5}$ Some of these approaches might even be applicable to the humanities as well. Underlying the free roam, precursor research approach in the fourth quadrant, for example, is "a conception more at home with the broader German idea of Wissenschaft than it is with French and Anglo-American ideas of science." (Ibid.) ${ }^{6}$

It must also be acknowledged that one unstated premise here is that there is a one-to-many relationship between quadrant and category of approach to research-a quadrant can include more than one category of approach to research. Manifesting this premise is Stokes' delicate use of the phrase "includes [a category of approach to] research," instead of "consists of," when describing the composition of each quadrant. For example, he stated that " $[\mathrm{t}]$ he lower right-hand cell [i.e., the Edison's quadrant in Fig. 2] includes research that is guided solely by applied goals without seeking a more general understanding of the phenomena of a scientific field." (Stokes 1997, p.74; italic by the author of this article) He used "this category [of research]" and "such a category [of research]" in each of the four quadrant definitions (Ibid., pp.74-75). This underlying premise, unstated yet manifested, provides an opportunity for the quadrants

\footnotetext{
5 John Maynard Keynes (1883-1946), British economist (The Editors of Encyclopaedia Britannica 2020a); the Manhattan Project, a US government research project (1942-1945) that produced the first atomic bombs (The Editors of Encyclopaedia Britannica 2020b); Irving Langmuir (1881-1957), American physical chemist who was awarded the 1932 Nobel Prize for Chemistry (Rice 2020).

${ }^{6}$ Often translated as science in the English language (e.g., MerriamWebster.com Dictionary 2020a), the German word Wissenschaft has a much broader meaning and includes humanities (van Bommel 2015, p.4). As a mass noun (Oxford English and Spanish Dictionary 2020), historically, it includes both "higher sciences" ("höhere Wissenschaften") and "faculty sciences" ("Fakultätswissenschaften"). The former category includes, inter alia, mathematics, physics, poetry, architecture, painting, music and dance; while the latter theology, law and medicine (Ibid.).
} 
Fig. 3 The Schön-Stokes model of research in socio-ecological systems (2017) [From Xiang (2017, p.2243), after Schön (1987/2001, p.191) and Stokes (1997, p.73)]

Quest for
fundamental
understanding
$\&$
Interest in
problems of
high ground

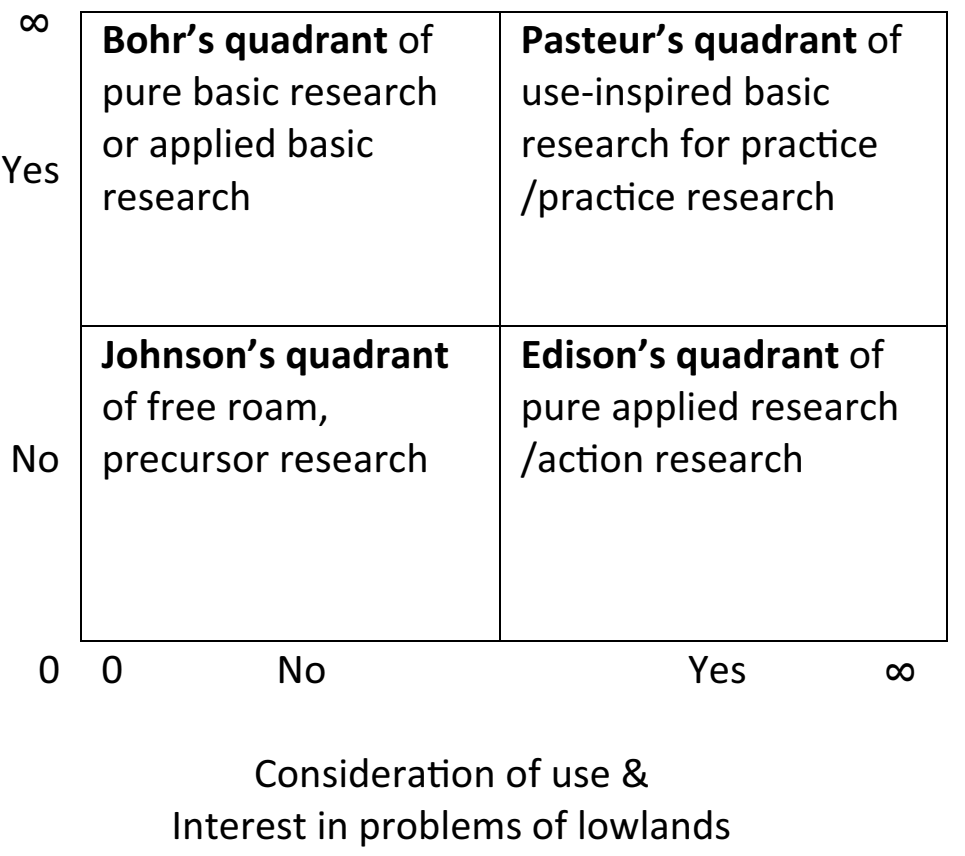

to include more research approaches. This opportunity is indeed seized and materialized in the RWC-Schön-Stokes model, as shown later in Sect. 4 of this article.

\section{The 2017 Schön-Stokes model of research in socio-ecological systems}

\subsection{A retrofit model}

Between 2016 and 2017 while working on an ecosystem services research project, I recast the Stokes quadrant model and named the descendant (Fig. 3) the Schön-Stokes model of research in socio-ecological systems (the Schön-Stokes model, for short). The name is so given that it acknowledges the inspirations from the intellectual heritage of both Donald Stokes and American philosopher and planning scholar Donald Schön (1930-1997) and highlights the new model's suitability for research use in socio-ecological systems. As exhibited at the beginning of this article (see Sect. 1), not only did the retrofit model help achieve two immediate research goals of the project, but it also started to gain traction among scholars from around the world.

What is new in the Schön-Stokes model (Fig. 3) that makes it suitable for research use in socio-ecological systems?

Compared to its ancestor (Fig. 2), the 2017 model has four added components. These are (1) a newly formulated dual dichotomy; (2) two distinctive classes of social system problems; (3) three additional approaches to researchapplied basic research, practice research and action research; and (4) designation of Johnson's quadrant. The first two are directly responsible for model's transformation and will be discussed below in the rest of this section. The three research approaches (the third added component) have been undergoing further development ever since and will be discussed in Sects. 4 and 5 with updates. An explanation of the designation of Johnson's quadrant was provided in Xiang (2017, p.2243).

\subsection{A newly formulated dual dichotomy}

The Schön-Stokes model includes two new research motivations, "interest in problems of high ground" and "interest in problems of lowlands"; and couples them, respectively, with the two preexisting research motivations (i.e., research goals) inherited from the Stokes quadrant model_ " "quest for fundamental understanding" and "consideration of use." This leads to two combined research motivations, "quest for fundamental understanding \& interest in problems of high ground" and "consideration of use \& interest in problems of lowlands." It then formulates a new dual dichotomy of research motivations and presents it via two intersecting axes (Fig. 3).

It should be noted that in Fig. 3, each ax exhibits a dichotomy of discrete yes or no categories on a continuum ranging from zero to infinity. This mixed way of presentation is inspired by and reflective of a dialectic view of Stokes'. In presenting the 1997 quadrant model, Stokes wrote, "There is not the slightest reason to think of these dimensions [of understanding and use] only in dichotomous terms, since there can be many degrees of commitment to these two goals. But if we do so for heuristic reasons, it is clear that we now have not one dichotomy but two." (Stokes 1997, p.72). 


\subsection{Two distinctive classes of social system problems}

Thanks to the above-mentioned coupling of research interests with research goals, two classes of social system problems are brought into play in the newly formulated dual dichotomy: problems of lowlands and those of high ground. Their presence in the newly formulated dual dichotomy helps make the Schön-Stokes model suitable for socio-ecological systems generally and for socio-ecological practice and socio-ecological practice research specifically.

\subsubsection{Problems of lowlands and those of high ground}

In 1987, Donald Schön presented these two classes of social system problems in a dichotomous setting of social practice research (Schön 1987/2001). According to him, when conducting research in the varied fields of social practice (e.g., education, law, medicine, management, planning and engineering), members of the research community are confronted with an important choice. Metaphorically, the choice is between descending to "the swampy lowlands" of real-world practice and standing on "the high ground" of ivory tower theory (Schön 1987/2001, p.191) ${ }^{7}$; associated with this dichotomous situation are two distinctive classes of social system problems. He wrote figuratively,

On the high ground, manageable problems lend themselves to solution through the use of researchbased theory and technique. In the swampy lowlands, problems are messy and confusing and incapable of technical solution. The irony of this situation is that the problems of the high ground tend to be relatively unimportant to individuals or to society at large, however great their technical interest may be, while in the swamp lie the problems of greatest human concern.

(Ibid.)

Of these two classes of social system problems, Donald Schön did not provide detailed account about the defining characteristics; nor did he acknowledge the groundbreaking seminal work on the very topic which, by the time of his writing, had been in existence for almost two decades (see 3.3.2 below). Nonetheless, the association he established here between research ambitions and target social system problems is brilliant. It is in fact the direct fountainhead of inspiration for the above-mentioned coupling of research interests with research goals in the new dual dichotomy of research motivations.

\footnotetext{
7 The noun ivory tower is referred to "an impractical often escapist attitude marked by aloof lack of concern with or interest in practical matters or urgent problems." (Merriam-Webster.com Dictionary 2020b).
}

\subsubsection{Wicked problems and tame problems}

"How is it that we can get to the moon when we can't get to the airport?".

Asked American planning scholar Melvin Webber (1920-2006) in a 1973 lecture at the University of Reading, UK (Batty 2014, p.30). With this intriguing leading question of fabled words, he enunciated the two classes of social system problems Donald Schön later noted only inexplicitly in 1987.

In the late 1960s, Melvin Webber and two fellow American scholars, Horst Rittel (1930-1990) and West Churchman (1913-2004), collectively identified a distinctive "class of social system problems which are ill-formulated, where the [available] information is confusing, where there are many clients and decision makers with conflicting values and where the ramifications in the whole system are thoroughly confusing ... [such that] proposed 'solutions' often turn out to be worse than the symptoms" (Churchman 1967, p.B141). In the two seminal articles (Churchman 1967; Rittel \& Webber 1973), they call these "wicked problems" and foresee that acknowledging their intractability and ubiquity would prompt a change in the ambitions and approaches of those charged to study and attend to them (Xiang 2013, p.1). ${ }^{8}$ As such, when asking the leading question about why "we can't get to the airport" at Reading in 1973, Melvin Webber must have had wicked problems in mind (Batty 2014, p.30).

The three American scholars named the other class of social system problems "tame problems". Being the primary research targets of mathematics, physical and natural sciences, technology and engineering, these problems could be extremely complicated but are "benign", "docile" and most definitely solvable (Rittel et al. 1973, p.160). Examples include, but are not limited to, the Goldbach Conjecture (Hosch 2009); atomic and molecular structure (Aaserud 2020); the technical obstacles to many Edison's inventions (Conot et al. 2020); preservation of beer, wine and milk (Ullmann 2020); and vaccination against anthrax and rabies (Ibid.). Unlike their wicked counterpart, tame problems often have exhaustive, crystal clear formulations (Rittel et al. 1973, p.161), as exemplified by the ambitious

\footnotetext{
8 [1] For reviews on wicked problems research, see Batty (2014, pp.29-33), Coyne (2005), Whyte \& Thompson (2001), Xiang (2013), Xiang (2019a, p.8), among others. [2] The characteristic of wicked problems, "proposed 'solutions' often turn out to be worse than the symptoms," can be expressed as being iatrogenic, in that solutions to an existing problem will almost inevitably induce new, equally if not more wicked problems that could be well beyond people's imaginations. For definition of iatrogenic, see Collins English Dictionary (2020).
} 
yet well-defined goal to "get to the moon" in Melvin Webber's leading question; and their solutions can be tested and determined "on the spot" (Ibid., p.163).

Over half of a century later, it is now widely recognized that wickedness, the ubiquity of wicked problems, is the norm in social systems of all kinds, including socio-ecological systems where human-human (social-economic-political-cultural- ...) relations and human-nature (ecological) relations are intertwined with each other (Xiang 2013, p.2; 2019a, p.8). Wicked problems are present in essentially all issue areas of socio-ecological practice that matter to the human society today (Xiang 2013, p.2; 2019a, p.8), ranging from global climate change adaptation and mitigation, human sustainability, urbanization, to poverty, hunger and the ongoing common threat imposed by the COVID-19 pandemic, ${ }^{9}$ to list just a few. Therefore, the inclusion of both wicked problems and tame problems, in the forms of "problems of lowlands" and "problems of high ground," respectively, helps transform the Stokes quadrant model into a new model that is suitable for research use in socio-ecological practice and socio-ecological practice research (Xiang 2017, p.2442). It is indeed an important addition.

\section{The 2020 RWC-Schön-Stokes model of research in socio-ecological systems}

As mentioned at the beginning of the article (subsection 1.2), I presented an updated version of the Schön-Stokes model at a workshop on November 20, 2020. Using it as a frame of reference, I highlighted the differences and similarities among seven approaches to research in socio-ecological systems (Xiang 2020a).

In this updated version, which I call the RWC-Schön-Stokes model of research in socio-ecological systems (the RWC-Schön-Stokes model, for short; see Fig. 4), I include the following changes:

1. In lieu of "problems of lowlands" and "problems of high ground," their more rigorously defined and widely accepted counterparts, "wicked problems" and "tame problems," are used in the definitions of research interests;

\footnotetext{
9 A common threat is by definition a danger-something or someone that can hurt or harm people - that might happen to every individual human being in a certain place (e.g., the earth, a country, a region, a city, a village, a community, etc.) to the extent that no one in that place is immune. The common threat imposed by the COVID-19 pandemic is a super wicked problem [Daniels et al. 2021, section "3 A counterfactual scenario for coping with the super wicked COVID problem by Jeffrey Chan"; Palko \& Xiang 2020, p.260; Xiang 2020c, p.200; and footnote 9 in Xiang (2021)].
}

2. To reflect that replacement and recognize the contribution of Horst Rittel, Melvin Webber and West Churchman, a three-letter abbreviation RWC is added to the model's name, in which $\mathrm{R}$ for Rittel, W for Webber and C for Churchman;

3. Three additional approaches to research are included and specified with examples - the Fuller approach to curiosity-inspired knowledge brokering research, the $\mathrm{McHarg}$ approach to use-inspired practice research for practice \& understanding and the $\mathrm{Li}$ approach to useinspired practice research for practice. These are more developed and updated versions of the three approaches in the Schön-Stokes model (see the last paragraph in subsection 3.1 and Fig. 3);

4. Each of these three new approaches is placed in a quadrant for which it is best fit;

5. The four existing approaches are renamed to keep up with the three newly incorporated approaches: the Bohr approach to curiosity-inspired pure basic research for understanding, the Pasteur approach to use-inspired basic research for understanding \& practice, the Edison approach to use-inspired pure applied research for practice and the Johnson approach to free roam, precursor research ${ }^{10}$;

6. Three quadrants are renamed in honor of six outstanding researchers whose achievements are compelling testimony to the effective research approaches they chose to employ: Bohr's quadrant is renamed Bohr-Fuller's quadrant, Pasteur's Quadrant Pasteur-McHarg's Quadrant and Edison's quadrant Edison-Li's quadrant.

The inclusion of three additional research approaches is strategic and justified. As explicated below in Sect. 5, these approaches to research are inherently "down-to-earth" in that they are developed and/or used by non-scientist researchers and/or applied scientist researchers in socioecological practice. For example, Ian McHarg, whose outstanding work exemplifies one of the three approaches, once proudly claimed himself a "crypto-pseudo-quasi-scientist" (McHarg 2007, p.21; Xiang 2019c, p.361). The presence of these approaches thus broadens the scope of the RWC-Schön-Stokes model significantly and makes it more relevant to and workable in socio-ecological practice and socio-ecological practice research. Further, incorporating additional research approaches is legitimate and permissible because of a premise underlying the 1997 Stoke quadrant model (discussed in subsection 2.3). That premise states that

\footnotetext{
10 The use of "approach to," instead of "approach of," in the naming of the seven approaches reflects the belief that there may well be other ways to conduct these three categories of research. For example, the McHarg approach is one way to conduct "use-inspired practice research for practice \& understanding."
} 


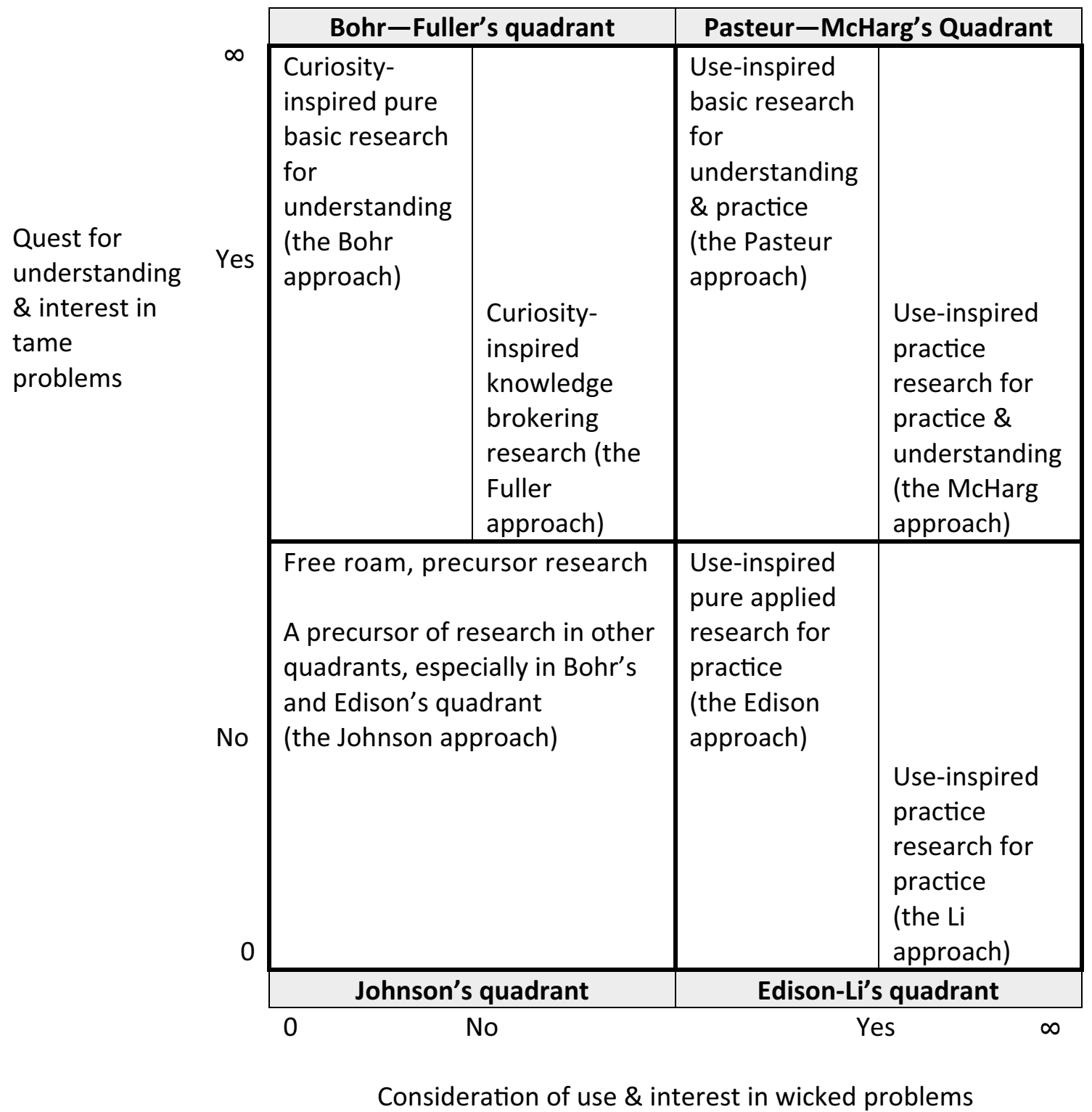

Fig. 4 The RWC-Schön-Stokes model of research in socio-ecological systems (2020) [After Xiang (2017, p.2243; 2019b, p.2; 2019c, p.362; 2020a)]

there is a one-to-many relationship between quadrant and category of approach to research-a quadrant can include more than one category of approach to research.

\section{Three added practical approaches in the RWC-Schön-Stokes model}

In compliance with the convention Donald Stokes used in defining the four approaches to research in his 1997 quadrant model (see first paragraph in subsection 2.3), I defined the three newly added approaches (see Fig. 4) via three real-world examples (Xiang 2020a). In each example, the approach a noted researcher used (but not necessarily developed) in socio-ecological practice exemplifies a corresponding approach in the RWC-Schön-Stokes model.

\subsection{The Fuller approach to curiosity-inspired knowledge brokering research}

R. Buckminster Fuller (1895-1983) is an American engineer and architect. As "one of the most original thinkers of the second half of the twentieth century," he "was noted for unorthodox ideas on global issues" (Marks 2020). He believes that following "a strategy that aimed at a radical solution of world problems by finding the means to do more 
with less ... [c]omprehensive and anticipatory [engineering and/or architectural] design initiative[s] alone-exclusive of politics and political theory-can solve the problems of human shelter, nutrition, transportation and pollution." (Ibid.) His 1960 Dome over Manhattan proposal best manifests this belief, which suggests covering Midtown Manhattan in New York City with a 3-km-diameter geodesic dome to regulate climatic conditions, curtail energy use and harvest rainwater (Budds 2016). It exemplifies cogently a curiosity-inspired approach to knowledge brokering research in socio-ecological practice.

Knowledge brokering is a process through which knowledge brokers "foster the linkage between the creators and users of knowledge" (Ward et al. 2009, p.269) and aim to "mobilize" or "inject" knowledge into users' decision-making activities (Kislov et al. 2017, p.111; Twiss 1975, p.235; Xiang 1996, p.1 \& p.8). Knowledge brokers here are applied scientist researchers or non-scientist researchers who help enable knowledge flow across previously separated groups of knowledge creators and users (Kislov et al. 2017, p.111; Ward et al. 2009, p.269). Out of the three presently codified classes of knowledge brokering activities-knowledge management, linkage and exchange and capacity building, only is knowledge management the best understood and most used in practice (Kislov et al. 2017, p.108; Ward et al. 2009, p.269) mainly because it is less time-consuming, less resource-intensive and easier to capture (Kislov et al. 2017, p.108). R. Buckminster Fuller's 1960 proposal exemplifies a common brokering activity of knowledge management, that is, sharing research results with decision makers and practitioners through experiments and/or demonstrations. Despite widely acknowledged as ineffective across many professional fields (Barber \& Rodman 1990, p.26; Ward et al. 2009, p.269; Xiang 2017, pp.2242-2244; 2019c, p.363), knowledge brokering activity of this kind remains popular and prevalent in socio-ecological practice and research (Xiang 2017, pp.2242-2244; 2019c, p.363). ${ }^{11}$

Furthermore, R. Buckminster Fuller's 1960 proposal exemplifies an approach to knowledge brokering research in socio-ecological practice that is primarily curiosity-driven. Under such an approach, researchers are inspired by both a general but strong sense of social responsibility and a genuine curiosity about whether or not and exactly how the "pure, objective and rational" knowledge (Cook \& Spray 2012, p. 93) can be made relevant to and even actionable for the

\footnotetext{
11 A more recent example is the proposal of stratospheric albedo modification (Cziczo et al. 2019; McClellan et al. 2012). In this proposal, researchers suggest that particulates of sulfur compounds be dispersed in the stratosphere of the earth's atmosphere and demonstrate how this engineering operation could reduce the effective solar flux entering the atmosphere and thus cool surface temperatures of the earth.
}

solution of real-world problems. Like the "creators" of this objective knowledge who are engaged in curiosity-inspired pure basic research for understanding in Bohr-Fuller's quadrant, most if not all of these "translators" also have little if any interest in attending to inherent wickedness in the real-world problems (Barber \& Rodman 1990, p.26). Their pertinent research pursuits are often funded through grants by a third party from outside the planning or design region and mainly focused on more effective translation and better communication of scientific theories and technological advancement to "inform," "influence" and "improve" practice (Palmer 2012, p.6).

\subsection{The McHarg approach to use-inspired practice research for practice $\&$ understanding}

Ian McHarg (1920-2001) is a Scottish-American landscape planner who is known for the 1969 landmark book Design With Nature and for his many successful "practice-grounded and knowledge-based research" projects in the USA (Steiner $\&$ Fleming 2019, p.173). These include, but are not limited to, the metropolitan open space study of greater Philadelphia (Daniels 2019, pp.199-201; McHarg 1969, pp.55-65), the plan for The Valleys in Baltimore County, Maryland (Daniels 2019, pp.201-202; McHarg 1969, pp.79-93), the Staten Island project, New York City (McHarg 1969, pp.103-115; Xiang 2014, p.66), the Interstate-95 in New Jersey project (McHarg 1969, pp.31-41), the planning and development of The Woodlands new town, Texas (Daniels 2019, PP.202-204; McHarg 1996, pp.256-264; Yang \& Li 2019, pp.217-219), the Potomac Report and Toward a Comprehensive Landscape Plan for Washington D.C. (Heavers 2019), among others.

As a scholar-practitioner, Ian McHarg is committed to generating new knowledge that is useful to practitioners and enlightening to fellow scholars (Herrington 2010, p.1; Steiner 2019a, p.34 \& p.36; Steiner \& Fleming 2019, p.173; Xiang 2019a, p.7 \& p.9; 2019c, p.359 \& p.367; 2019d, p.165). Through writing, practice and advocacy, he "fundamentally changed socio-ecological practice and research" (Steiner \& Fleming 2019, p.173); many of his ideas, methods and theories have been and continue to be benefiting diverse fields, ranging from ecological planning and design, geographic information science, environmental sciences, geography, to law, the social sciences and even the humanities (Herrington 2010, p.1, pp.16-17; Steiner 2019a, p.34, p.36; Steiner \& Fleming 2019, p.173). ${ }^{12}$

\footnotetext{
12 [1] A collection of most recent articles on Ian McHarg's enduring legacy is published in a 2019 special issue of this journal (volume 1, combined issue 3-4). It is entitled Design With Nature at 50: retrospect and prospect and guest-edited by American landscape archi-
} 
As such, his work indeed manifests and exemplifies a three-pronged approach to socio-ecological practice research under which a research project (1) originates from practice, (2) proceeds for practice and (3) goes beyond practice. This approach is commonplace among other noted scholar-practitioners. These include, but are not limited to, Chinese urban planner Huang Guangyu [黄光宇 (1935-2006)], American landscape planner John T. Lyle (1934-1998), "the 'father of American landscape architecture'-Frederick Law Olmsted, Sr." (1822-1903) (Fabos 1979, p.48), American landscape architects and educators Julius Gy. Fabos and Frederick R. Steiner and American conservationist Aldo Leopold (1887-1948). ${ }^{13}$

\subsection{The Li approach to use-inspired practice research for practice}

The Chinese engineer Li Bing (李冰) lived in China during the Warring States period (480 BC-221 вс). ${ }^{14}$ As the general manager of Shu county (蜀郡) in the Qin Kingdom (秦国), he masterminded and led the construction of one of the world's oldest large-scale ecological-hydraulic projects (Needham et al. 1971, p.288; Xiang 2014, pp.65-66). The Dujiangyan irrigation system (都江堰灌溉系统) was first built in 256 BC under Li's leadership and has been further developed and expanded over the past 2300 years. It lays out an ecological infrastructure on the Chengdu Plain (成 都平原) that grants the $6,687 \mathrm{~km}^{2}$ region (roughly the size of the state of Delaware in the USA) a permanent immunity against natural liabilities of deluge and drought and offers tens of millions of people across generations the benefits of

\footnotetext{
Footnote 12 (continued)

tect and educator Frederick R. Steiner and colleague Billy Fleming from the University of Pennsylvania, USA (Steiner \& Fleming, 2019). It includes a succinct biography (Whitaker \& Steiner 2019) and an updated bibliography (Steiner 2019b). [2] Besides those cited already, for McHarg's enduring influences on theories, see Bryant \& Turner (2019), Lamb (2019) and Steiner (2019a); on education, Cohen (2019); on ecological planning, Lieberknecht (2019), Lim (2019) and Mainzer et al. (2019); on academia, practice and government, Palazzo \& Hollstein (2019). For McHarg's international influence, see Evans (2019) and Scott et al. (2019).

13 A collection of most recent articles on Aldo Leopold's enduring legacy is published in a 2020 special issue of this journal (volume 2, issue 1). It is entitled A Sand County Almanac at 70 and guestedited by Singaporean ecological philosopher Lin Qi Feng from the Nanyang Technological University, Singapore (Lin 2020a \& 2020b). The special issue features articles by American Leopold scholar Curt Meine (2020) and sociologist Paul Van Auken (2020) and includes a selected bibliography for socio-ecological practice researchers (Lin 2020c)

${ }^{14}$ In compliance with the official Chinese language conventionfamily name + given name, the Pinyin translation of 李冰 is Li Bing instead of Bing Li.
}

agricultural irrigation, municipal water supply, navigation, aquatic production, ecological conservation and tourism (Cao et al. 2010, p.5; Li et al. 2006, p.291; Needham et al. 1971, p.288; Peng 2008, p.542). Its sustained success has been attributed largely to the ecophronetic, holistic, adaptive principles Li Bing improvised contextually at the onset (Peng 2008, p.540; Xiang 2014, p.67; 2016, p.58) which guided every step of the project life cycle, from planning, design and construction of the system, to its operation, maintenance and governance (Cao et al. 2010, p.5; Peng 2008, pp. 539-542, p.544; Zhang et al. 2013, p.539).

Li Bing's work exemplifies a two-pronged approach to socio-ecological practice research under which a research project originates from practice and proceeds solely for practice. Unlike the scholar-practitioner Ian McHarg who strives to advance both practice and general understanding, the practitioner Li Bing aims exclusively to find the right way to do the right thing for a particular instance of socio-ecological practice and leaves no record of his research on the undergirding principles. It is only two millennia later when these scientific and managerial principles were extrapolated from the design characteristics of the irrigation system [Xiang 2019c, p.363; for reviews of these principles, see Cao et al. (2010), Li et al. (2006)]. One telling example is provided later in subsection 6.2.2 of this article.

\section{Five insights about the seven approaches}

The seven approaches to research included in the RWC-Schön-Stokes model represent different yet complementary ways of methodical knowing in socio-ecological practice and socio-ecological practice research. Their systematic arrangement in the fourfold table (see Fig. 4) provides an examination and comparison framework for people to seek insights that would otherwise be inconspicuous. Presented below are five insights about similarities, differences and connections among these approaches that I gained via the framework (Xiang 2020a).

\subsection{The "from practice, for practice and beyond practice" approaches}

The two approaches in the Pasteur-McHarg's quadrant (see Fig. 4), the Pasteur approach to use-inspired basic research for understanding \& practice and the McHarg approach to use-inspired practice research for practice \& understanding, aim for the dual ambition of improving practice and advancing understanding. Toward this end, research projects under both approaches necessarily originate from practice, proceed for practice and go beyond practice (Xiang 2019a, p.10; see discussions in subsections 2.2 and 5.2 of this article). This 
three-pronged way of methodical knowing is quintessential ecopracticology - the study of socio-ecological practice (Xiang 2019a, p.10) and the two approaches best instantiate it.

There are two main differences between the two approaches.

\subsubsection{Varied vantage points and foci on practice}

Despite both approaches originate research activities from practice, they view practice from different vantage points and take on different aspects of practice as their object of inquiry.

The Pasteur approach is a basic research approach developed and used by scientist researchers. Under this approach, researchers take on a practical problem practitioners encounter in their practice (e.g., preservation of beer and wine, reduction of airport's noise impacts, world hunger, climate change adaptation and mitigation, human sustainability), examine it through a scientific, often disciplinary lens and develop scientific research questions about one or several key aspects of the practical problem. These selected aspects of the real-world problem then become their object of inquiry. Their research findings are expected to and often do, contribute to the solution of the practical problem and meanwhile advance general understanding of the scientific mechanisms underlying the problem and justifying the solution.

The McHarg approach is a practice research approach developed and used by non-scientist researchers and/or applied scientist researchers. Under this approach, researchers take as the object of inquiry a concrete situation of practice real-world practitioners are engaged in [e.g., phased allocation of COVID-19 vaccines (Dooling 2020), planning a greenway, designing an urban park, attending to NIMBY (not in my back yard) issues associated with public facility allocation]. In each concrete situation, they perceive and accept the world as an irreducible whole which mandates a full consideration of wickedness and requires a holistic and pragmatic way of thinking and acting (Xiang 2020b, pp.122-123). They develop research questions from the totality of the situation and search for answers about what to do and how to act effectively and ethically in the concrete situation to achieve intended consequences that practitioners care about (Ibid.).

\subsubsection{Theories of practice vs theories of science}

The theories researchers aim to develop under the two approaches are by nature different from each other.

Under the Pasteur approach, scientist researchers pursue theories of science for general understanding about the scientific mechanisms underlying the practical problem and justifying its solution. These theories aim to comprise "pure, objective and rational" knowledge (Cook \& Spray 2012, p. 93) and strive to meet the requirements for generality, parsimony, consilience and predictiveness - the four qualities scientists look for in theories of science, according to American biologist EO Wilson (Wilson 1998, p.198).

Under the McHarg approach, non-scientist researchers strive to develop theories of practice. These theories are by nature theories of particularity about "extremes," not theories of generality about "averages" (McKelvey 2006, pp.827-828; Xiang 2019a, p.9). They consist of beliefs, ideas, policies, procedures and underlying rationales about what works, what doesn't, what matters ethically in each concrete situation and why (Argyris et al. 1974, pp.6-12; Bolan 1980, pp.263-264; Couclelis 1991, pp.382-383; Xiang 2019a, p.10; Xiang 2020b, pp.122-123).

Despite their situation-specific nature, theories of practice such developed, when worked well in concrete situations, are study-worthy to those academic theoreticians who are interested in developing general theories of practiceacademics' theories of practice (Xiang 2020b, p.123). As demonstrated by the influential works of noted academic theoreticians, academics' theories of practice, drawing on what practitioners did in concrete situations, may prescribe how other practitioners in comparable situations should act and justify why (Innes 1995, p.183; Mao 1937, p.300; Xiang 2019a, pp.8-10; Xiang 2020d, p.109). Academic works of this caliber include, but are not limited to, those by Ancient Greek philosopher Aristotle (Xiang 2020b, pp.121-123), American planning scholars Judy Innes (1942-2020) and John Forester (Ibid., footnote 5 on page 122), Chinese ecological planning scholar-practitioner Huang Guangyu (Huang \& Chen 2002) and of course those by Ian McHarg (McHarg 1969; 2007).

\subsection{The "from practice, for practice" approaches}

The two approaches in the Edison-Li's quadrant (see Fig. 4), the Edison approach to use-inspire pure applied research for practice and the $\mathrm{Li}$ approach to use-inspired practice research for practice, aim to achieve the sole ambition of advancing practice. Toward this end, research projects under both approaches necessarily originate from practice, proceed for practice and end in practice (See discussions in subsections 2.2 and 5.2). This two-pronged way of methodical knowing is commonplace among non-scientist researchers and/or applied scientist researchers in socio-ecological practice.

A major difference between the two approaches lies in their ways of searching for the target knowledge needed to understand and/or resolve practical problems. 


\subsubsection{An outsourcing approach for knowledge users}

Under the Edison approach, non-scientist researchers and/or applied scientist researchers act more as users of knowledge than creators of knowledge, two terms borrowed from and as defined in the knowledge brokering literature (Ward et al. 2009, p.269; see also discussions in subsection 5.1 of this article). To understand and/or resolve the practical problems in hand, they turn to knowledge brokers for the target knowledge needed. Sometimes, applied scientist researchers play a dual role of knowledge user and translator. This outsourcing approach is best exemplified by the way Thomas Edison conducted much of his pure applied research for invention. Writes Donald Stokes in his 1997 book (p.24; italics by the author of this article),

[W] holly uninterested in the deeper scientific implications of his discoveries, Edison gave five years to creating his utility empire, but no time at all to [understanding] the basic physical phenomena underlying his emerging technology [of marketable electric lighting]. When others persuaded him that his primitive grasp of these things would ultimately limit his engineering ventures, he, ... ran up the white flag of surrender, confessed that he never had understood these matters and [instead] hired some technicians trained in Maxwellian field theory. ${ }^{15}$

American historian of science and technology Bruce J. Hunt provides yet another account on Edison's outsourcing approach to pure applied research (Hunt 1983, p.355; italics by the author of this article):

The quintessential "half-educated electrician" Edison [sic], after a long struggle against alternating current, essentially gave up work in power engineering once it was adopted. He retained mathematical physicists to answer questions on electricity. "I've come to the conclusion," he said ruefully in 1892 , "that I never did know anything about it." Authority in the electrical world had passed into the hands of the scientists.

\subsubsection{An in-house approach for knowledge creators}

By contrast, under the Li approach, non-scientist researchers and/or applied scientist researchers act more as creators of

\footnotetext{
15 The following passage by historian Bruce J. Hunt helps keep this instance in a historical perspective. "Maxwell's theory of the electromagnetic field reached maturity in the last third of the nineteenth century; in these same years, the new electrical industries were advancing rapidly and beginning to transform Western life. It took some time for the new theory to penetrate electrical practice; it was not common for engineers to use Maxwellian theory in their work until the 1890s or even later." (Hunt 1983, p.341).
}

knowledge than users of knowledge. Take Li Bing's Dujiangyan irrigation system project in $256 \mathrm{BC}$ as an example. According to Chinese historian Peng Bangben, before and during the project, Li Bing and his fellow non-scientist researchers performed systematic watershed surveys of the Minjiang River (岷江), the river from which the irrigation system would divert water to the Chengdu Plain; and conducted many in situ "on spot investigation[s]" (Peng 2008, p.544). Through these research activities, collectively they generated a body of "rich extensive knowledge" about many socio-ecological phenomena and natural and social processes in the region (Ibid., p.547). Drawing on these understandings, they made plans, crafted designs and developed implementation procedures for every step of the project life cycle, from planning, design and construction of the system, to its operation, maintenance and governance (Ibid., pp.542-545). As the project proceeded and more knowledge and experience became available, they kept perfecting plans, designs and implementation procedures. Through this integrated, seamless "know-do" nexus, ${ }^{16}$ they built a practicegrounded, time-tested body of "local knowledge with universal significance" which manifests in and contributes to the very success and stunning longevity of the irrigation system (Ibid., p.533 \& p.544). As such, Li Bing and his fellow nonscientist researchers are indeed creators of knowledge and serving as a characteristic example of those non-scientist researchers who develop novel knowledge mainly if not entirely from practice and solely for practice. ${ }^{17}$

It is noteworthy that the contextual knowledge such developed, when proved to be true and useful by the instance of practice it is created for, is necessarily scientific. For example, "harnessing shoals deep, building dams low" (深 淘滩, 低作堰) is a 6-character protocol Li Bing developed 2300 years ago for the critical annual maintenance (岁修) of the irrigation system's headworks and has been followed strictly by the local people ever since (Peng 2008, p.544). Underlying this ancient phrase in plain Chinese language there turns out to be a "profound [modern] scientific law" that Li Bing evidently "fully understood and used" far before it was formally codified by modern-day scientists ( $\mathrm{Li}$ et al. 2006, p.294; Peng 2008, p.544). This same hydraulic principle of "water cross-circulation at curved river reaches" is also found in the engineering design of Feishayan (飞沙 堰), a "very effective" spillway for flushing sediment at the headworks of the irrigation system ( $\mathrm{Li}$ et al. 2006, p.294; Zhang et al. 2013, p.545).

\footnotetext{
16 The term "know-do" is borrowed from the knowledge brokering literature (Kislov et al. 2017, p.107 \& p.111). A "know-do" nexus is the opposite of "know-do" gap.

17 Another example for the use of this in-house approach in socioecological practice is the 1960s' Red Flag Canal project in Henan province, China (see Chen \& Xiang 2020a-b; Xiang 2020d).
} 


\subsection{A quartet of approaches manifesting the Bush linear model}

In Fig. 4, an imaginative diagonal line from the upper left corner to the lower right corner will cross four approaches. In a top-down sequence, these are the Bohr approach to curiosity-inspired pure basic research for understanding; the Fuller approach to curiosity-inspired knowledge brokering research; the Edison approach to use-inspired pure applied research for practice; and the Li approach to use-inspired practice research for practice. They form a perfect quartet of knowledge creator, knowledge broker and knowledge user, exhibiting the enduring influence of the Bush linear model (see Fig. 1).

The conceptual evolution of ecological resilience is a case in point.

In a 1973 seminal article "Resilience and stability of ecological systems," Canadian ecologist Crawford Holling uses the term resilience to describe a property of natural ecosystems he observed through curiosity-inspired pure basic research with the Bohr approach. He defines the resilience of ecological systems [that is, ecological resilience in the subsequent literature, see Gunderson (2000)] as "a measure of ... their [i.e., ecosystems'] ability to absorb change and disturbance and still maintain the same relationships between populations or state variables." (Holling 1973, p.14) Since then, a wealth of new knowledge has been generated about the art and science of ecological resilience (for reviews, see Biggs et al. 2015; Gunderson 2000; Wu and $\mathrm{Wu} 2013$ ) and about the practice of building ecological resilience in human-dominated ecosystems - urban areas (For recent reviews, see Beller et al. 2018; Meerow et al. 2016; Romero-Lankao et al. 2016). Some of these reported works in urban resilience building are results of curiosity-inspired knowledge brokering research with the Fuller approach and best exemplified by the seven principles for building resilience in socio-ecological systems proposed by South African scholar Reinette Biggs and two fellow scholars in 2015 (Biggs et al. 2015). Other works are results of either use-inspired pure applied research with the Edison approach or use-inspired practice research with the Li approach and exemplified by the projects showcased in a 2014 book by American research psychologist Judith Rodin entitled "The resilience dividend: being strong in a world where things go wrong" (Rodin 2014).

\subsection{The wickedness-savvy vs wickedness-blind approaches}

Out of the four use-inspired research approaches in the RWC-Schön-Stokes model (Fig. 4), the practice-grounded McHarg and Li approaches are wickedness-savvy, in that they are capable of "working with" wicked problems prudently through an "AAA" strategy-awareness, acceptance and adaptation (Xiang 2013, p.3). Their more science- and/or technology-focused counterparts, the Pasteur approach and the Edison approach, are much less if ever involved in wicked problems directly and thus mostly wickedness-blind.

Equally if not more wickedness-blind are the two approaches in the Bohr-Fuller's quadrant. For the Bohr approach to pure basic research, attending to wickedness is completely out of the question. The Fuller approach to knowledge brokering research, even when aspiring to, is incapable of working with wicked problems properly. This is because, as many point out, it tends to treat socio-ecological practice as an experiment field or demonstration site of scientific principles and/or technological advancement, instead of a dignified object of inquiry with its own integrity (Buchanan 1992, p.19; Innes 1995, pp. 183-184; Xiang 2017, pp. 2243-2244). To make findings from pure basic research relevant to and/or workable in "the uncertain, subjective and biased [real-world] contexts of human understanding, social factors and governance" (Cook et al. 2012, p. 93), researchers under this approach almost always have to adopt "procrustean strategies" (Schön 1987/2001, p. 192) so that the wicked problems can be cut-to-fit available theories and techniques (Churchman 1967, p. B-142; Schön 1987/2001, pp. 192-193; Xiang 2017, p. 2243). They often formulate and use imaginative practitioners who are in speculative needs for a certain target knowledge within an artificialized rational context (Churchman 1967, pp. B-141-B142; Schön 1987/2001, p. 188, pp. 191-193; Xiang 2017, p. 2244).

What about the Johnson approach-is it wickedness savvy or blind? Given the free roam, precursor nature of the approach, suffice it to say that the answer really depends upon the direction (which quadrant, that is) researchers head to under this rambling but often necessary and sometimes productive approach.

\subsection{Effectiveness in knowledge creation}

In his 1997 book, Donald Stokes demonstrates with credible evidence that the Pasteur approach to use-inspired basic research is as effective in knowledge creation for general understanding as the Bohr approach to curiosity-inspired pure basic research. Below I use an example from a 2019 article of mine (Xiang 2019d, p.166) to show that the McHarg approach to use-inspired practice research is also as effective as the Bohr approach in creating new knowledge that advances general understanding.

Around the same time Crawford Holling publicized his conception of ecological resilience in 1973 (see discussions in 6.3), Ian McHarg came up with a novel and "profoundly simple concept" of building ecological resilience for the 
planning and development of The Woodlands new town, Texas, USA (McHarg 1996, p. 260) The concept is pure and simple-"to determine densities and land use from the geohydrological properties of the soils"(Ibid.). Using this concept, he and fellow non-scientist researchers developed a comprehensive ecological (instead of engineering) plan for urban-flooding-repellent development and implemented it efficaciously to guide the new town's development (Lyle 1999 , p. 103, p. 237; McHarg 1996, pp. 259-264; Xiang 2016, pp. 56-57; 2019d, pp.166-167; Yang 2019, pp. 69-75; Yang and Li 2019, pp. 24-29).

Since it was first built in the 1970s, the town has been enjoying what Judith Rodin calls "the resilience dividend" (Rodin 2014) against urban flooding that McHarg and his colleagues promised in their ecological plan yet without using the term ecological resilience (Xiang 2019d, p.167). In a more recent instance during Hurricane Harvey in August 2017, wrote American landscape planning scholar Bo Yang,

there were very few flooded streets in The Woodlands and almost none existed in the early-built villages that were more faithful to McHarg's [ecological] plan. It is evident that The Woodlands demonstrated a greater level of [ecological] resilience to flood than its adjacent communities and Houston [the most populous city in Texas, $45 \mathrm{~km}$ south of The Woodlands], ... The sharp contrast of flood resilience is a result of The Woodlands' comprehensive ecological plan [McHarg and his colleagues first developed in the 1970s], which

Houston lacks. (Yang 2019, pp.213-214)

As there is no evidence found in the literature that Holling and McHarg had any intellectual contact directly or indirectly (Xiang 2019d, p.167), does this coincidence of human achievements suggest that Holling and McHarg be "epistemically privileged" (Kidd, 2015, p.345) equally in discovering truth, one as a scholar-scientist and the other a non-scientist researcher (Xiang 2019d, p.167)? Does this also suggest that their distinct approaches to research be methodologically advanced equally?

Yes, indeed (Ibid.).

\section{A model whose results inspire more lines of inquiry}

"All models are wrong," wrote British statistician George Edward Pelham Box (1919-2013) in 1976, but some models "can often derive results which match, to a useful approximation, those found in the real world." (Box 1976, p.792) If and when this is the case, models are heuristically useful (Ibid.; Sterman 2002, p.521). The RWC-Schön-Stokes model may well be qualified to be such a model.
The results it derives speak for themselves. The seven approaches the model codified and presented "match those found in the real world"- they represent, "to a useful approximation," ways of methodical knowing and acting that real-world researchers developed and used in socioecological practice and socio-ecological practice research. Their systematic arrangement in the fourfold table (Fig. 4) is testimony to how non-competitive and even complementary these vastly different yet equally legitimate approaches are "found in the real world" - each of them works effectively in its own niche to serve certain unduplicated research needs.

Furthermore, these cogent results are heuristically evocative. They prompt general queries about (1) how researchers may understand and embrace multiple ways of methodical knowing that are reflective of our contemporary world (Patel et al. 2019, p.270) and (2) how researchers may take full advantage of the entirety of these approaches in socioecological practice and socio-ecological practice research. From these arise questions concerning, inter alia, researchers' entitlement and responsibility to awareness, choice and use of the seven approaches. More specifically,

\section{The right to know}

Should researchers, be they scientists or non-scientists, be morally and professionally entitled to know that there are seven (and potentially more) different, non-competitive and even complementary approaches to research available in socio-ecological practice and socio-ecological practice research?

2. The privilege to choose and use

Should researchers be morally, professionally and legally entitled to choose and use one or any combination of the seven alternative approaches that best fits the concrete research situation they find themselves in?

3. The ability to choose and use

Should researchers be morally, intellectually and professionally capable of choosing and using one or any combination of the seven approaches that best fits the concrete research situation they find themselves in?

4. The responsibility to awareness, choice and use

Should it be researchers' professional and social responsibility to know about and exercise their right and privilege above-mentioned and to be able to make right choice and use the selected approach effectively in their research projects?

To some of us, these questions seem oddly reminiscent of a familiar phrase on our college or professional school diplomas-“... with all the rights, privileges and dignities appertaining to that degree." Nonetheless, the questions, in their very own right, could likely lead to serious, fine-grained inquiries into an important strategy in socio-ecological practice and socio-ecological practice research—upholding 
methodological pluralism (Xiang 2019a, p.10). Similarly, they could also inspire explorations of what could be called "researcher's bill of rights" in the study of socio-ecological practice. ${ }^{18}$ These and other possible emerging lines of inquiry are worth our while to pursue, I trust.

Acknowledgements I thank the following individuals who made comments and suggestions on the Schön-Stokes model, while I was giving presentations in the past several years: Jianguo Wu (Arizona State University, USA), CY Jim (The Education University of Hong Kong, China), Xinhao Wang (University of Cincinnati, USA), Yan Wentao, Wang Yuncai and Chen Chundi (all with Tongji University, China), Wang Hui (Nanjing Forestry University, China), and Courtney Flint (Utah State University, USA). I am indebted to Brent Heard at the National Academies of Sciences, Engineering and Medicine in Washington, DC, for inviting me to give a presentation at the workshop on November 20,2020. The present article crystalizes many ideas emerged during the preparation for the presentation and benefits from presentations of two other panelists at the workshop, Dustin Schroeder (Stanford University, USA) and Danielle Wood (Massachusetts Institute of Technology, USA). I am grateful to two longtime colleagues who, on the condition of anonymity, provided critical yet constructive comments on an early version of this article.

\section{References}

Aaserud F (2020) Niels Bohr: Danish physicist. Encyclopædia Britannica, November 14, 2020. https://www.britannica.com/biogr aphy/Niels-Bohr (accessed December 06, 2020)

Argyris C, Schön DA (1974) Theory in practice: increasing professional effectiveness. Jossey-Bass Publishers, San Francisco

Armacost MH (1997) Forward. In: Stokes DE (1997) Pasteur's quadrant: basic science and technological innovation. Brookings Institution Press, Washington, D.C.

Barber KH, Rodman SA (1990) FORPLAN: the marvelous toy. J Forest 88(5):26-30

Batty M (2014) Great planning disasters. In: Tewdwr-Jones M, Phelps NA, Freestone R (2014) (Eds) The planning imagination: Peter Hall and the study of urban and regional planning. Routledge, London. 28-39

Beller EE, Spotswood EN, Robinson AH et al (2018) Building ecological resilience in highly modified landscapes. Bioscience 69(1):80-92

Biggs R, Schluter M, Schoon ML (eds) (2015) Principles for building resilience: sustaining ecosystem services in social-ecological systems. The Cambridge University Press, Cambridge

Bolan RS (1980) The Practitioner as theorist: the phenomenology of the professional episode. Journal of the American Planning Association 46(3):261-274. https://doi.org/10.1080/0194436800 8977042

\footnotetext{
18 [1] Methodological pluralism is "the doctrine that, rather than slavish attachment to a limited number of scientific or research methods, a proliferation of methodologies and theories often pays off" (Collins dictionary of sociology 2006). The opposite is methodological monism, "the doctrine that there is, or even could be, a single formalized set of historically invariant, context insensitive methodological norms" (Kidd, 2015, p345). [2] "Researcher's bill of rights" is the title of a 2004 article by American sociologist Harry Perlstadt (2004). He used the term with a focus different from the one in this article.
}

Box GEP (1976) Science and statistics. Journal of the American Statistical Association 71(356):791-799. https://doi. org/10.1080/01621459.1976.10480949

Bryant MM, Turner JS (2019) From thermodynamics to creativity: McHarg's ecological planning theory and its implications for resilience planning and adaptive design. Socio-Ecological Practice Research 1(3-4):325-337. https://doi.org/10.1007/s4253 2-019-00027-1

Buchanan R (1992) Wicked problems in design thinking. Design Issues $8(2): 5-21$

Budds D (2016) How Buckminster Fuller made a dome over Manhattan sound sensible. A never-before-published interview with the inventor details how he rationalized radical urban ideas. Fast Company, https://www.fastcompany.com/3058386/how-buckm inster-fuller-made-a-dome-over-manhattan-sound-sensible (accessed November 1, 2020)

Bush V (1945) Science: the endless frontier. A Report to the President, United States Government Printing Office, Washington, D.C.

Cao SY, Liu XN, Er HA (2010) Dujiangyan irrigation system-a world cultural heritage corresponding to concepts of modern hydraulic science. Journal of Hydro-Environment 4(1):3-13

Chen C, Wang Y, Jia J, Mao L, Meurk C (2019) Ecosystem services mapping in practice: a Pasteur's quadrant perspective. Ecosystem Serverces 40:101042

Chen Y, Xiang W-N (2020a) Why was Tao Lujia so willing and swift to greenlight the Red Flag Canal Project in 1960? The instance and his reflections. Socio-Ecological Practice Research 2(4):329335. https://doi.org/10.1007/s42532-020-00060-5

Chen Y, Xiang W-N (2020b) Why was Tao Lujia so willing and swift to greenlight the Red Flag Canal Project in 1960? New insights via a lens of compassion practice. Socio-Ecological Practice Research 2(4):337-346. https://doi.org/10.1007/s42532-02000061-4

Churchman CW (1967) Wicked problems. Manage Sci 14(4):B141-B142

Cohen WJ (2019) The legacy of Design with Nature: from practice to education. Socio-Ecological Practice Research 1(3-4):339-345. https://doi.org/10.1007/s42532-019-00026-2

Collins dictionary of sociology (2006) Methodological pluralism. In Jary D, \& Jary J (Eds.), Collins dictionary of sociology. (4th ed.). [Online]. Collins, London. Available from: https://go.openathens .net/redirector/uncc.edu?url=https $\% 3 \mathrm{~A} \% 2 \mathrm{~F} \% 2 \mathrm{Fsearch} . c r e d o$ reference.com $\% 2$ Fcontent $\% 2$ Fentry $\% 2$ Fcollinssoc $\% 2$ Fmethodol ogical_pluralism\%2F0\%3FinstitutionId\%3D5899 (Accessed 4 January 2021).

Collins English Dictionary (2020) Iatrogenic. Collins English Dictionary. https://www.collinsdictionary.com/dictionary/english/iatro genic (accessed December 22, 2020)

Conot RE, Josephson M (2020) Thomas Edison: American inventor Encyclopædia Britannica, October 14, 2020. https://www.brita nnica.com/biography/Thomas-Edison (accessed December 06, 2020)

Cook BR, Spray CJ (2012) Ecosystem services and integrated water resource management: different paths to the same end? J Environ Manage 109:93-100

Couclelis H (1991) There is nothing as theoretical as good practice. Environment and Planning B: Planning and Design 18:379-384

Coyne R (2005) Wicked problems revisited. Des Stud 26(1):5-17

Cziczo DJ, Wolf MJ, Gasparini B et al (2019) Unanticipated side effects of stratospheric albedo modification proposals due to aerosol composition and phase. Scientific Reports 9:18825. https ://doi.org/10.1038/s41598-019-53595-32

Daniels T (2019) McHarg's theory and practice of regional ecological planning: retrospect and prospect. Socio-Ecological Practice Research 1(3-4):197-208. https://doi.org/10.1007/s42532-01900024-4 
Daniels T, Chan JKH, Kankam S, Murphy M, Day D, Fürst C, Inkoom JN, Koo H (2021) Four shareworthy SEPR scenario ideas. SocioEcological Practice Research. https://doi.org/10.1007/s4253 2-020-00072-1

Dooling K (2020) Phased allocation of COVID-19 vaccines. ACIP COVID-19 Vaccines Work Group, ACIP meeting, December 20, 2020. https://www.cdc.gov/vaccines/acip/meetings/downl oads/slides-2020-12/slides-12-20/02-COVID-Dooling.pdf (Accessed January 11, 2020)

Evans BM (2019) Reimagining Design with Nature: ecological urbanism in Moscow. Socio-Ecological Practice Research 1(3-4):233-247. https://doi.org/10.1007/s42532-019-00031-5

Fabos JG (1979) Planning the total landscape: a guide to intelligent land use. Westview Press, Boulder

Feng Y, Han Y, Fan Q, Zhang X, Liu J (2019) A visualized review of ecological planning and design based on bibliometrics from 1992 to 2017. International Review for Spatial Planning and Sustainable Development 7(1):101-116

Gibson EK (2020) Overseeing innovation: 75 years after Vannevar Bush's impactful report, debate continues about directing science. Science 369(6501):258-259

Gunderson LH (2000) Ecological resilience-in theory and application. Annual Review of Ecological Systems 31:425-439

Hagemann FA, Randrup TB, Sang AO (2020) Challenges to implementing the urban ecosystem service concept in green infrastructure planning: a view from practitioners in Swedish municipalities. Socio-Ecological Practice Research 2(3):283-296

Heavers N (2019) Ian McHarg's enduring influence on the ecological planning and design of Washington's waterfront. Socio-Ecological Practice Research 1(3-4):179-196. https://doi.org/10.1007/ s42532-019-00015-5

Herrington S (2010) The nature of Ian McHarg's science. Landscape Journal 29(1):1-10

Holling CS (1973) Resilience and stability of ecological systems. Annu Rev Ecol Syst 4:1-23

Hosch WL (2009) Goldbach conjecture. Encyclopædia Britannica, April 08, 2009. https://www.britannica.com/science/Goldbachconjecture (accessed December 15, 2020)

Huang GY, Chen Y (2002) Ecocity: theory and design approach (In Chinese). China Science Publishing \& Media, Beijing. [黄光 宇、陈勇 (2002) 《生态城市理论与规划设计方法》, 北京: 科学出版社]

Hunt BJ (1983) "Practice vs. Theory": the British electrical debate, 1888-1891. Isis, 74(3): 341-355

Innes JE (1995) Planning theory's emerging paradigm: communicative action and interactive practice. Journal of planning education and research 14:183-189

Jim CY (2019) Resolving intractable soil constraints in urban forestry through research-practice synergy. Socio-Ecological Practice Research 1(1):41-53. https://doi.org/10.1007/s42532-018-00005 $-\mathrm{Z}$

Kidd IJ (2015) What's so great about Feyerabend? Against Method, forty years on Paul Feyerabend: Against Method, 4th edition. Metascience. 24; 343-349

Kislov R, Wilson P, Boaden R (2017) The "dark side" of knowledge brokering. Journal of Health Services Research \& Policy 22(2):107-112

La Rosa D (2019) Why is the inclusion of the ecosystem services concept in urban planning so limited? A knowledge implementation and impact analysis of the Italian urban plans. Socio-Ecological Practice Research 1(2):83-91. https://doi.org/10.1007/s4253 2-019-00016-4

Lamb Z (2019) The politics of designing with nature: reflections from New Orleans and Dhaka. Socio-Ecological Practice Research 1(3-4):227-232. https://doi.org/10.1007/s42532-019-00019-1
Li K, Xu ZF (2006) Overview of Dujiangyan irrigation system scheme of ancient China with current theory. Irrigation and Drainage 55(3):291-298

Lieberknecht K (2019) Building and innovating upon McHarg's ecological survey: the Texas case. Socio-Ecological Practice Research 1(3-4):283-296. https://doi.org/10.1007/s42532-01900025-3

Lim T (2019) Use of the McHargian LUSA in agricultural research and decision-making in the age of non-stationarity and big earth observation data. Socio-Ecological Practice Research 1(3-4):297-324. https://doi.org/10.1007/s42532-019-00022-6

Lin QF (2020) A Sand County Almanac at 70: the significance of Leopold's life-work for socio-ecological practice and research. Socio-Ecological Practice Research 2(1):1-2. https://doi. org/10.1007/s42532-020-00046-3

Lin QF (2020) Aldo Leopold's life-work and the scholarship it inspired. Socio-Ecological Practice Research 2(1):3-30. https:// doi.org/10.1007/s42532-020-00043-6

Lin QF (2020) Aldo Leopold: a selected and annotated bibliography for socio-ecological practice researchers. Socio-Ecological Practice Research 2(1):63-70. https://doi.org/10.1007/s42532-020-00045 $-4$

Lyle JT (1999) Design for human ecosystems: landscape, land use and natural resources. Island Press, Washington, DC

Mainzer SP, Cole CA, Flohr T (2019) Deep decarbonization and renewable energy in the Appalachian Mountains (DDREAM): a socioecological systems approach to evaluating ecological governance. Socio-Ecological Practice Research 1(3-4):249-263. https ://doi.org/10.1007/s42532-019-00030-6

Mao T-T (1937) On practice: on the relation between knowledge and practice, between knowing and doing. In: Foreign Language Press (1967): Selected works of Mao Tse-Tung, 1: 295-309. Foreign Language Press, Beijing, China [This is a translation of the below essay in the first Chinese edition of Mao's book (1951)]

Marks RW (2020) R. Buckminster Fuller: American engineer, architect and futurist. Encyclopædia Britannica, July 08, 2020. https:// www.britannica.com/biography/R-Buckminster-Fuller (Accessed December 28, 2020)

McClellan J, Keith DW, Apt J (2012) Cost analysis of stratospheric albedo modification delivery systems. Environmental Research Letters. 7; 034019 (8pp). https://doi.org/10.1088/1748$9326 / 7 / 3 / 034019$

McHarg IL (1969) Design with nature. Doubleday/Natural History Press, Garden City, New York

McHarg IL (1996) A quest for life: an autobiography. John Wiley \& Sons, New York

McHarg IL (2007) The theory of creative fitting. In: Margulis L, Corner J, Hawthorne B (eds) Ian McHarg: conversations with students: dwelling in nature. Princeton Architectural Press, New York, pp 19-61

McKelvey B (2006) Response: Van de Ven and Johnson's “engaged scholarship": Nice try, but .... Acad Manag Rev 31(4):822-829

Meerow S, Newell JP, Stults M (2016) Defining urban resilience: a review. Landscape and Urban Planning 147:38-49

Meine C (2020) From the land to socio-ecological systems: the continuing influence of Aldo Leopold. Socio-Ecological Practice Research 2(1):31-38. https://doi.org/10.1007/s42532-020-00044 $-5$

Merriam-Webster.com Dictionary (2020a) Wissenschaft. MerriamWebster.com dictionary. https://www.merriam-webster.com/dicti onary/Wissenschaft (accessed December 7, 2020)

Merriam-Webster.com Dictionary (2020b) Ivory tower. MerriamWebster.com dictionary. https://www.merriam-webster.com/dicti onary/ivory\%20tower (accessed December 13, 2020)

National Academies of Sciences, Engineering, and Medicine (2020) The endless frontier: the next 75 years in science. The National 
Academies Press, Washington, DC. https://doi.org/10.17226 125990

Needham J, Wang L, Lu G-D (1971) Science and civilization in China. Volume4: Physics and physical technology, Part III: Civil engineering and nautics. Cambridge University Press, Cambridge, UK

Oxford English and Spanish Dictionary (2020) Wissenschaft. Oxford English and Spanish Dictionary, Thesaurus and Spanish to English Translator. https://www.lexico.com/definition/wissenschaft (accessed December 7, 2020)

Palazzo D, Hollstein L (2019) Ian McHarg's confident skill. SocioEcological Practice Research 1(3-4):347-357. https://doi. org/10.1007/s42532-019-00028-0

Palko HC, Xiang W-N (2020) In fighting common threats, people's deep commitment to taking collective action matters: examples from China's COVID-19 battle and her other combats. Socio-Ecological Practice Research 2(3):257-264. https://doi. org/10.1007/s42532-020-00056-1

Palmer MA (2012) Socioenvironmental sustainability and actionable science. Bioscience 62(1):5-6

Patel L, Smagorinsky P, Dixon-Román E (2019) In dialogue: methodological pluralism. Research in the teaching of English 53(3):270-277

Peng B (2008) Dujiangyan irrigation system: a case of East Asia local knowledge with universal significance. Frontiers of History in China 3(4):533-550

Perlstadt H (2004) The researcher's bill of rights. Medical Humanities Report, 25(2) http://ethics.iit.edu/EEL/Perlstadt\%20Bill\%20 of\%20Rights.pdf (Accessed January 13, 2021)

Rice RE (2020) Irving Langmuir: American chemist. Encyclopædia Britannica, August 12, 2020. https://www.britannica.com/biogr aphy/Irving-Langmuir (accessed December 06, 2020)

Rittel HWJ, Webber MM (1973) Dilemmas in a general theory of planning. Policy Sci 4:155-169

Rodin J (2014) The resilience dividend: being strong in a world where things go wrong. Public Affairs, New York

Romero-Lankao P, Gnatz DM, Wilhelmi O, Hayden M (2016) Urban sustainability and resilience: from theory to practice. Sustainability, 8(12), 1224; doi:https://doi.org/10.3390/su8121224

Scholz RW, Steiner G (2015) Transdisciplinarity at the crossroads. Sustain Sci 10:521-526

Schön D (1987/2001) The crisis of professional knowledge and the pursuit of an epistemology of practice. In: Raven J (Ed) Competence in the Learning Society, 183-207. Peter Lang, New York

Scott D, Bogunovich D, Bradbury M (2019) Designing Aotearoa New Zealand with nature: landscape regeneration of Western Waiheke Island. Socio-Ecological Practice Research 1(3-4):265-281. https://doi.org/10.1007/s42532-019-00034-2

Steiner F (2019) Toward an ecological aesthetic. Socio-Ecological Practice Research 1(1):33-37. https://doi.org/10.1007/s4253 2-018-00004-0

Steiner F (2019b) Ian L. McHarg: a bibliography. Socio-Ecological Practice Research, 1(3-4): 381-396. https://doi.org/10.1007/ s42532-019-00021-7

Steiner F, Fleming B (2019) Design With Nature at 50: its enduring significance to socio-ecological practice and research in the twenty-first century. Socio-Ecological Practice Research 1(34):173-177. https://doi.org/10.1007/s42532-019-00035-1

Sterman J (2002) All models are wrong: reflections on becoming a systems scientist. System Dynamics Review 18(4):501-531

Stokes DE (1997) Pasteur's quadrant: basic science and technological innovation. Brookings Institution Press, Washington, D.C.

The Editors of Encyclopaedia Britannica (2020a) John Maynard Keynes: British economist. Encyclopædia Britannica, June 01, 2020. https://www.britannica.com/biography/John-MaynardKeynes (accessed December 6, 2020)
The Editors of Encyclopaedia Britannica (2020b) Manhattan Project. Encyclopædia Britannica, September 10, 2020. https://www. britannica.com/event/Manhattan-Project (accessed December $6,2020)$

The National Academies of Sciences, Engineering and Medicine (2020). Advancing a systems approach to studying the earth: a strategy for the National Science Foundation. Washington, DC. https://www.nationalacademies.org/our-work/advancing-a-syste ms-approach-tostudying-the-earth-a-strategy-for-the-nationalscience-foundation

Tijssen RJW (2018) Anatomy of use-inspired researchers: from Pasteur's Quadrant to Pasteur's Cube model. Res Policy 47(9):1626-1638

Twiss RH (1975) Nine approaches to environmental planning. In: Burchell RW, Listokin D (eds) Future land use: energy, environmental and legal constraints. Center for Urban Policy Research, Rutgers-The State University of New Jersey, New Brunswick, NJ, pp 235-242

Ullmann A (2020) Louis Pasteur: French chemist and microbiologist. Encyclopædia Britannica, September 24, 2020. https://www. britannica.com/biography/Louis-Pasteur (accessed December 06, 2020)

U.S. National Archives \& Records Administration (2020) Thomas Edison's patent application for the light bulb (1880). https://www. ourdocuments.gov/doc.php?flash $=$ false $\&$ doc $=46$ (accessed December 6, 2020)

Van Auken P (2020) Toward a fusion of two lines of thought: creating convergence between Aldo Leopold and sociology through the community concept. Socio-Ecological Practice Research 2(1):39-61. https://doi.org/10.1007/s42532-020-00042-7

Van Bommel B (2015) Between "Bildung" and "Wissenschaft": The 19th-century German ideal of scientific education. Institut für Europäische Geschichte. http://ieg-ego.eu/en/threads/model s-and-stereotypes/germanophilia-and-germanophobia/bas-vanbommel-between-bildung-and-wissenschaft-the-19th-centu ry-german-ideal-of-scientific-education (accessed December 5, 2020)

Wang YC, Shen JK, Xiang W-N (2018) Ecosystem service of green infrastructure for adaptation to urban growth: function and configuration. Ecosystem Health and Sustainability 4(5):132-143

Ward V, House A, Hamer S (2009) Knowledge brokering: the missing link in the evidence to action chain? Evidence \& Policy 5(3):267-279

Whitaker W, Steiner F (2019) Ian L. McHarg: an illustrated chronology of his life. Socio-Ecological Practice Research, 1(3-4): 371-380.https://doi.org/10.1007/s42532-019-00032-4

Whyte KP, Thompson PB (2001) Ideas for how to take wicked problems seriously. J Agric Environ Ethics 25:441-445. https://doi. org/10.1007/s10806-011-9348-9

Wilson EO (1998) Consilience: the unity of knowledge. Alfred A, Knopf, New York, USA

Wu J, Wu T (2013) Ecological resilience as a foundation for urban design and sustainability. In: Pickett STA, Cadenasso ML, McGrath B (Eds.) Resilience in ecology and urban design: linking theory and practice for sustainable cities, 211-229. Springer

Xiang W N (1996) GIS-based riparian buffer analysis: injecting geographic information into landscape planning. Landscape and Urban Planning 34(1):1-10

Xiang W-N (2013) Working with wicked problems in socio-ecological systems: awareness, acceptance and adaptation. Landscape and Urban Planning 110(1):1-4

Xiang W-N (2014) Doing real and permanent good in landscape and urban planning: ecological wisdom for urban sustainability. Landscape and Urban Planning 121:65-69 
Xiang W-N (2016) Ecophronesis: the ecological practical wisdom for and from ecological practice. Landscape and Urban Planning 155:53-60

Xiang W-N (2017) Pasteur's quadrant: An appealing ecophronetic alternative to the prevalent Bohr's quadrant in ecosystem services research. Landscape Ecol 32(12):2241-2247

Xiang W-N (2019a) Ecopracticology: the study of socio-ecological practice. Socio-Ecological Practice Research 1(1):7-14

Xiang W-N (2019b) Socio-Ecological Practice Research (SEPR): what does the journal have to offer? Socio-Ecological Practice Research 1(1):1-5 https://doi.org/10.1007/s42532-018-0001-y

Xiang W-N (2019c) Why did history vote many times in his favor? Four reasons for McHarg's achievements in socio-ecological practice research. Socio-Ecological Practice Research 1(3-4):359-369. https://doi.org/10.1007/s42532-019-00023-5

Xiang W-N (2019d) History voted many times in Ian McHarg's favor. Socio-Ecological Practice Research 1(2):165-169. https://doi. org/10.1007/s42532-019-00013-7

Xiang W-N (2020a) Similarities and differences among the seven approaches to research in socio-ecological systems: insights from the Schön-Stokes model of research. An invited plenary presentation at "Integrating earth systems science and engineering: a virtual workshop", hosted by the National Academies of Sciences, Engineering and Medicine of the United States, November 20, 2020 ( https://www.nationalacademies.org/event /11-20-2020/advancing-a-systems-approach-to-studying-theearth-a-strategy-for-the-national-science-foundation-integratin g-earth-systems-science-and-engineering-a-virtual-workshop) The PPT used in the presentation is available from the author upon request (wxiang@uncc.edu)

Xiang W-N (2020b) From good practice for good practice we theorize; in small words for big circles we write. Socio-Ecological Practice Research 2(1):121-128. https://doi.org/10.1007/s4253 2-020-00040-9

Xiang W-N (2020c) Why does SEPR publish people's COVID-19 experience, observations and reflections? Socio-Ecological Practice Research 2(3):199-203. https://doi.org/10.1007/s4253 2-020-00066-Z

Xiang W-N (2020d) The Red Flag Canal: a socio-ecological practice miracle from serendipity, through impossibility, to reality.
Socio-Ecological Practice Research 2(1):105-110. https://doi. org/10.1007/s42532-019-00037-z

Xiang W-N (2020e) Pursuing an honorable and humble quality of mind, exploring an ethical and phronetic path to planning (in Chinese). In: Han Haoying (2020) The Chinese translation of "Planning with complexity: an introduction to collaborative rationality for policy" (In Chinese). China Science Publishing \& Media, Beijing. iii-xiii. (象伟宁 《追求无己无功无名无常 心的精神境界, 探讨面对非理性挑战的智慧规划途径》。收 录在韩吴英2020译作《规划顺应复杂-公共政策的协作理性 简介》第iii-xiii页, 北京: 科学出版社)

Xiang W-N (2021) Re-examination research via the COVID glasses: an intellectual movement emerging for the better. Socio-Ecological Practice Research. https://doi.org/10.1007/s42532-020-00071-2

Yang B (2019) Landscape performance: Ian McHarg's ecological planning in the Woodlands. Texas, Routledge, London and New York

Yang B, Li S (2019) Blending project goals and performance goals in ecological planning: Ian McHarg's contributions to landscape performance evaluation. Socio-Ecological Practice Research 1(3-4):209-225. https://doi.org/10.1007/s42532-019-00029-z

Zhang SH, Yi YJ, Liu Y, Wang XK (2013) Hydraulic principles of the 2268-year-old Dujiangyan project in China. Journal of Hydraulic Engineering-ASCE. 139(5); 538-546

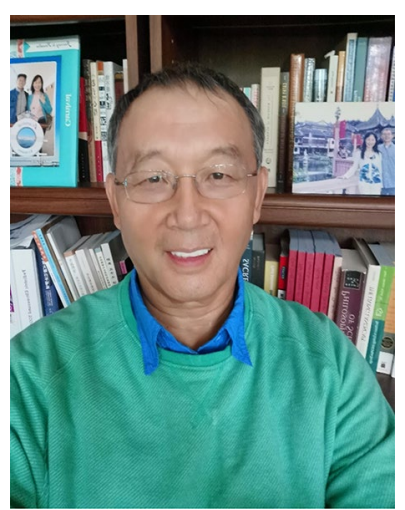

Wei-Ning Xiang is a Professor of Geography and Earth Sciences at the University of North Carolina at Charlotte, USA (1990-present); the former co-editor-inchief of Landscape and Urban Planning (2011-2018), he is the founding editor-in-chief of Socio-Ecological Practice $\mathrm{R} \mathrm{e} \mathrm{s} \mathrm{e} \mathrm{a} \mathrm{r} \mathrm{c} \mathrm{h} \mathrm{(} \mathrm{S} \mathrm{E} \mathrm{P} \mathrm{R} \mathrm{)}$ (2019-present). 